\title{
Hydrolysis Methods for Protein Extraction from Seafood
}

\author{
Vu Hoang Gia Han ${ }^{1}$, Tran Thi Bich Phuong ${ }^{2}$ and Tran Duy Hai ${ }^{2 *}$ \\ ${ }^{1}$ Faculty of Applied Sciences (Student Code: 61702101), Ton Duc Thang University, Vietnam \\ ${ }^{2}$ Faculty of Environmental Engineering, Ho Chi Minh city University of Natural Resources and Environment, Vietnam
}

*Corresponding author: Tran Duy Hai, Faculty of Environmental Engineering, Ho Chi Minh city University of Natural Resources and Environment, Vietnam.

To Cite This Article: Vu Hoang Gia Han, Tran Thi Bich Phuong, Tran Duy Hai. Hydrolysis Methods for Protein Extraction from Seafood. Am J Biomed Sci \& Res. 2020 - 11(3). AJBSR.MS.ID.001630. DOI: 10.34297/AJBSR.2020.11.001630.

Received: 泚 November 25, 2020; Published: 眥 December 18, 2020

\begin{abstract}
Seafood-based material has been impressive as a promising proteins source for food process. Hydrolysates from seafood hydrolysis, containing essential amino acids and short-chain peptides for human health, are in high nutritive value. Selected properties of the seafood hydrolysis are presented in this review, focusing on enzymatic and acid hydrolysis techniques. Advantages, disadvantages and optimal conditions are also briefly summarized.
\end{abstract}

Keywords: Protein extraction; Hydrolysis; Seafood Processing; Nutrients

\section{Introduction}

Many essential compounds for human body such as nucleic acid, hormones, co-enzyme, eicosapentaenoic acid (EPA), docosahexaenoic acid (DHA), etc. can be produced from broken proteins [1]. In terms of sources, seafood is supplying ca. $39 \%$ of the total protein demand of humans. Protein from seafood is easier digestibility, higher biological value and more quality than most meats and vegetables [2]. Proteins present not only in seafood muscle, where contains a large amount of protein, but also in by-products (i.e. head, bones, fins and skin). Proteins in seafood can be extracted and functionalized in order to produce valuable ingredients for pharmaceutical and medical technologies, especially utilization for humans with imbalance and uncontrollability of nitrogen.

Solvent, physic, enzymatic and acid hydrolysis are methods, which are widely being applied for proteins extraction with different qualities and efficiencies [3]. The structure of recovered protein molecules can be intact with the solvent and physical methods [4]. Oppositely, long-chain proteins in seafood can be broken, generating in high valuable short-chain peptides i.e. essential amino acids, in the enzymatic and acid hydrolysis [2]. The enzymatic extraction was found to be a higher yield and faster rate than ultrasonic extraction [5]. Hydrolysis indicates a sustainable method for proteins extraction from various sources (plant, animal, algae) in food processing, resulting in proteins hydrolysates.

\section{Enzymatic Hydrolysis}

Protease enzymes cleave long-chain protein at special chemical bonds and generate a mixture of free amino acids and oligopeptides that own better biological, digestible and functional properties for health [6]. Enzyme, substrate and processing conditions influence product yield and quality. In the traditional process, exogenous enzymes (occurrence in bromelain, ficin and papain) can increase fish fermentation rate, producing a protein hydrolysats like fish sauce [7]. The enzymatic proteins extraction is easily performed due to low processing temperature (least than $60^{\circ} \mathrm{C}$ ) and neutral media, which are advantageous conditions for the growth of desired enzymes. The yield of seafood hydrolysis rapidly increases in initially and tend to constants with hydrolysis time beyond necessary (c.a. 5 h) [8]. Both the antioxidant activity and abundance 
of free amino acids of Pro, Leu, Ala, Trp and Phe from enzymatic seafood hydrolysis increase with the prolonged hydrolysis time [9]. Table 1 summarizes results from several reports.

The enzymatic hydrolysis is an alternative method for the food industry due to high the functionality and nutritive value of protein hydrolysates. However, low reaction rate, high cost, media yield and difficult enzyme recovery are disadvantages [10].

\section{Acid Hydrolysis}

Proteins structure can be destroyed under strong acid $(\mathrm{HCl}$, H2SO4) to produce lactic acid [11] as the final product instead of intermediates (dipeptides or amino acid) from the enzymatic

Table 1: Summarized results of enzymatic seafood hydrolysis.

\begin{tabular}{|c|c|c|c|}
\hline Material & Processing conditions & Product & Reference \\
\hline \multirow{3}{*}{ Cod } & \multirow{3}{*}{ Enzyme: Alcalase $2.4 \mathrm{Au}-\mathrm{A} / \mathrm{g}$,; $\mathrm{pH} 7 ; \mathrm{m}: \mathrm{w}=1: 2$, time: $1 \mathrm{~h}$} & Yield: $61.8 \%$ & \multirow{3}{*}{ Liaset et al. [19] } \\
\hline & & TEAA: $36.6 \pm 7 \%$ & \\
\hline & & THAA: $69.6 \pm 4 \%$ & \\
\hline \multirow{3}{*}{$\begin{array}{c}\text { Heads of Chlorurus } \\
\text { sordidus }\end{array}$} & \multirow{3}{*}{ Endogenous enzyme; $\mathrm{m}: \mathrm{w}=1: 2, \mathrm{pH} 9$, time: $24 \mathrm{~h}$} & Yield : 41.67\% & \multirow{3}{*}{ Prihanto et al. [9] } \\
\hline & & TEAA: $41.7 \%$ & \\
\hline & & THAA: $41 \%$ & \\
\hline Mackerel Fish & Enzyme source: bromelain (10\%), pH7.5, m:w = 1:1, time: $4 \mathrm{~h}$ & Yield: $50.82 \%$ & Ramakrishnan et al. [8] \\
\hline \multirow{2}{*}{$\begin{array}{l}\text { Seabream consisted of } \\
\text { head }\end{array}$} & \multirow{2}{*}{ Enzyme: Alcalase $2.4 \mathrm{Au}-\mathrm{A} / \mathrm{g}, \mathrm{pH} 8 ; \mathrm{m}: \mathrm{w}=1: 1$, time: $3 \mathrm{~h}$} & Yield: 80.9\% & \multirow{2}{*}{ Valcarcel et al. [20] } \\
\hline & & TEAA: $41.94 \%$ & \\
\hline
\end{tabular}

AU: Anson Unit; m:w: Material and water ratio (w/w); TEAA: Total essential amino acid; THAA: total hydrophobic amino acid

\section{Improving Hydrolysis}

Optimizing hydrolysis conditions and combining new technologies have recently been approached to improve enzymatic protein extraction yield and quality of a product. Positive effects of ultrasound to proteases performance were observed and indicated by $61.76 \%$ of protein hydrolysis yield with rainbow trout substrate in Alcalase 2.4 enzyme [14]. Isopropanol and ethanol solvents and mechanical separations can be applied to remove of lipids and insoluble material in enzymatic hydrolysis that upgraded product quality [15]. Moreover, amino acids from seafood hydrolysis in presence of the catalysts could polymerize to di-, tri- or/and tetrapeptides, and then separated by precipitation [16].

While the application of chemical solvent can help adjust properties of proteins hydrolysates, processing parameters can optimize cost and yield. Sajib et al. [17] enzymatic-based hydrolyzed (Clupea harengus) with Box-Behnken design, which advanced parameter control, achieving in $77.28 \%$ of hydrolysis yield. Enzyme can be immobilized on a fixed-media in a continuous reactor, promoting applications on a large scale [18].

\section{References}

1. Khawli FK, Pateiro M, Domínguez R, Lorenzo MJ, Gullón P, et al. (2019) Innovative Green Technologies of Intensification for Valorization of Seafood and Their By-Products. Mar Drugs 17(12): 689. hydrolysis. Following neutralization, the hydrolysates contain a large amount of salt, resulting in suitable utilization of the obtained hydrolysate for flavor and taste enhancement. In right controlled conditions, seafood protein hydrolysate with the $\mathrm{HCl}$ hydrolysis indicates a promising product with its nutritive value (TEAA $=2.33 \%$ ) [12]. Distillated acid hydrolysate from seafood can also be used as a microbial media. Acid hydrolysis depend extremely on acid activity, temperature and pressure. Proteins extraction yield reduces with higher acid concentrations [13].

To improve fish proteins extraction for food consideration, acid hydrolysis can be applied as a pre-treatment step for enzymatic hydrolysis in the next step. 
12. Wisuthiphaet N, Klinchan S, Kongruang S (2016) Fish protein hydrolysate production by acid and enzymatic hydrolysis. KMUTNB Int J App Sci Technol 9(44): 261-270.

13. Nicharee W, Sasithorn K (2015) Production of Fish Protein Hydrolysates by Acid and Enzymatic Hydrolysis. Journal of Medical and Bioengineering 4(6): 466-470.

14. Misir GB, Koral S (2019) Effects of ultrasound treatment on structural, chemical and functional properties of protein hydrolysate of rainbow trout (Oncorhynchus mykiss) by-products. Ital J Food Sci 31(2): 205223.

15. Siddik MAB, Howieson J, Fotedar R, Partridge GJ (2020) Enzymatic fish protein hydrolysates in finfish aquaculture: a review. Reviews in Aquaculture 13(1): 12520.

16. Tavano OL, Angel BM, Secundo F, Roberto FL (2018) Biotechnological Applications of Proteases in Food Technology. Comprehensive reviews in Food Sciences and Food Safety 17(2): 412-436.
17. Sajib M, Albers E, Langeland M, Undeland I (2020) Understanding the effect of temperature and time on protein degree of hydrolysis and lipid oxidation during ensilaging of herring (Clupea harengus) filleting co-products. Scientific Reports 10: 9590.

18. Sewczyk T, Antink MH, Maas M, Kroll S, Beutel S (2018) Flow rate dependent continuous hydrolysis of protein isolates. AMB Express 8: 18.

19. Liaset B, Lied E, Espe M (2000) Enzymatic hydrolysis of by-products from the fish-filleting industry: chemical characterization and nutritional evaluation. J Sci Food Agric 80(5): 581-589.

20. Valcarcel J, Sanz N, Vázquez JA (2020) Optimization of the Enzymatic Protein Hydrolysis of By-Products from Seabream (Sparus aurata) and Seabass (Dicentrarchus labrax), Chemical and Functional Characterization. Food 9(10): 1503-1515. 